\title{
STUDY OF BIOTECHNOLOGY RAISE ANTIOXIDANT PROPERTIES OF OLIVE OIL AND BLACK SEED OIL
}

\author{
Mahmoud Shaheen $^{1 凶}$, N. V. Dolganova ${ }^{1}$, Elena Vladimirovna Shinkar ${ }^{2}$, Lyudmila Timofeevna \\ Sukhenko², Oksana Vitalevna Astafieva ${ }^{2}$ \\ 1 "Technology of Goods and Commodity Research" Department FSBEI HE "Astrakhan State Technical \\ University", \\ 2 "Biotechnology, Zoology and Aquaculture" DepartmentFSBEI HE "Astrakhan State Technical University", \\ $\otimes_{\text {shaxin77@mail.ru }}$ \\ https://doi.org/10.34302/crpjfst/2020.12.2.15 \\ Article history: \\ Received: \\ 20 September 2019 \\ Accepted: \\ 10 April 2020 \\ Keywords: \\ Olive oil; \\ Black seed; \\ Oil antioxidant properties; \\ Organoleptic properties

\begin{abstract}
The aim of this study was to improve the functional and antioxidant properties of olive oil using $10 \%, 15 \%, 20 \%$ and $25 \%$ black oil as a substitute. The compositions of olive oil with black cumin seed oil were created to develop the formulation of the product with enhanced functional and antioxidant properties. Antioxidant properties of olive oil, black cumin seed oil and the obtained compositions of olive oil with black cumin oil were studied by chemical and photometric methods. The results showed that olive oil with the addition of $15 \%-20 \%$ black cumin seed oil is optimal both in antioxidant activity and organoleptic properties. Therefore,
\end{abstract} \\ this oil composition can be recommended as a functional edible oil.
}

\section{Introduction}

Olive oil from European olivium (Olea europaea L.) is one of the most important foods that is in increasing demand all over the world, which makes it possible to increase values and antioxidant properties (Makarova and Borodinova, 2011). As additives that increase antioxidant properties, olive oil can be used as enzymatic and lipolytic properties, from which derived medicinal preparations. Unlike other vegetable oils, black cumin oil (Nigella sativa L.) contains such essential unsaturated fatty acids as (linoleic -55-65\%; oleic -15-18\%; palmitic -10-12\%; eicosenic - 4- 5\%; stearic $1-3 \%$; alpha-linolenic - 1\%), lipase, tocopherols, multivitamins, groups A, B, P, essential oils, enzymes and other components (http://www.gabris.ru/gabris /). health / cumin / oil), also has strong bactericidal and antiseptic properties (Elshafey et al., 2014).However, the compositions for comparison with the original oils and olive oil. It is known that black cumin oil has a bitter unusual taste. Therefore, studies of the organoleptic characteristics and antioxidant activity of various compositions with different mass fractions of oil in olive oil are relevant (Lemekhova et al., 2011).These studies showed an increase in the functional and antioxidant properties of olive oil using $10 \%, 15 \%, 20 \%$ and $25 \%$ black oil as a substitute (Khasanov et al. 2004).

\section{Materials and methods}

\subsection{Materials}

Sampling of oils for the study of organoleptic and antioxidant quality indicators was made in supermarkets in Astrakhan. Oil samples were taken from the fruit of extradition planted olives produced in Italy (Borgeos Olive Oil, Carapelli Olive Oil). Black cumin seed oils (chernushki) were purchased from the central market outlets (FitOil Black Cumin Seed Oil, NigOil Black Cumin Seed Oil). Samples of oils from black cumin seeds and olive fruits were 
prepared for research: A - FitOil black cumin seed oil; B - black cumin seed oil NigOil; C Borgeos olive oil; D - Carapelli olive oil.

\subsubsection{The composition of olive oil}

The composition of olive oil (Borgeos) with the addition of black seed oil (FitOil) to it in the following\% ratios: $\mathrm{E}-90: 10(\%)(\mathrm{A}: 10 \%)$; F - 85:15 (\%) (A: 15\%), G - 80:20 (\%) (A: $20 \%)$ and $\mathrm{H}-75: 25$ (\%) (A: 25\%).

\subsection{The antioxidant properties of vegetable oils}

The antioxidant properties of vegetable oils and their compositions were investigated by a chemical method described (Fabris, et al., 2013), which consists in the colorimetry of free stable radicals based on the reaction of an antioxidant sample (AH) with DPPH dissolved in ethanol (2,2-diphenyl -1-picrylhydrazyl (C18H12N5O6, M = 394.33). A DPPH test (DPPH) was performed by photometric method with 0.5 millimolar (mmol) DPPH alcohol solutions (Sigma-Aldrich) at a wavelength of $517 \mathrm{~nm}$, measured on an AP- 101 (APEL, Japan). The working solutions of the samples were prepared on $96 \%$ ethyl $\mathrm{m}$ alcohol; measurements were carried out 60 minutes after the start of the reaction of DPPH with a sample of antioxidant (AH) (Kouakou et al., 2018.) The degree of radical seizure - $\mathrm{P} \%$ and antioxidant activity - AA\% were calculated. $\mathrm{P} \%$ was calculated using the formula: $\mathrm{P}(\%)=$ $[(\mathrm{But}-\mathrm{NaOH}) / \mathrm{But}] \mathrm{x} 100 \%$, where Ho and Naooh are the height of the photometric signal in the absence and presence of antioxidant, respectively (Shpigun et al., 2010). AA in $\%$ was calculated using the formula: $\mathrm{AA}=[1-$ (Ai-Aj) / Ac] $x 100 \%$, where $\mathrm{Ai}$ is the absorption of the test solution with a DPPH reagent, $\mathrm{Aj}$ is the absorption of the test substance, Ac is the absorption of a DPPH solution (Fabris et al., 2013).In parallel, the potential antioxidant activity was determined by the method of cyclic voltammetry (Baizer and Lund, 1988). To remove cyclic voltammograms (CVA), a potentiostat "IPCPro", coupled with IBM, was used as a three- electrode, diaphragm-free cell $(\mathrm{V}=2 \mathrm{ml})$. A platinum electrode $(\mathrm{D}=1 \mathrm{~mm} 2)$ was used as a working one, the reference electrode was $\mathrm{Ag} /$ $\mathrm{AgCl}$ in a saturated $\mathrm{KCl}$ solution with a waterproof diaphragm, the auxiliary electrode was platinum ( $\mathrm{S}=70 \mathrm{~mm} 2$ ) (Baizer and Lund, 1988).As a background electrolyte, nBu4NClO4 $(\mathrm{C}=0.1 \mathrm{M})$ was used to increase the electrical conductivity of the analyzed solutions (Bordwell ang Cheng, 1989). Samples of oils were dissolved in methylene chloride, which was purified by the method. The method is based on the ability of organic components of oils with biological activity to be oxidized to a one-electron stage at a certain potential value under the conditions considered.

\section{Results and discussions}

The antioxidant activity of the studied samples of oils from the fruits of olives and black cumin seeds is presented in Table 1 and the graph in Figure 2. The highest degree of radical seizure of a stable free radical (DPPH) by the samples studied was found in oils of black cumin seeds of sample A and sample B, slightly lower than the antioxidant activity in olive oil sample $C$, then sample D.

Table1. Comparative studies of the antioxidant properties of various samples of olive oil and black cumin oil

\begin{tabular}{|l|l|l|}
\hline Test substance & $\begin{array}{l}\text { The degree of } \\
\text { radical } \\
\text { seizure, } \%\end{array}$ & $\begin{array}{l}\text { Antioxidant } \\
\text { activity,\% }\end{array}$ \\
\hline $\begin{array}{l}\text { Black Cumin Seed Oil } \\
\text { FitOil - A }\end{array}$ & 117,7 & 129,23 \\
\hline $\begin{array}{l}\text { Black Cumin Seed Oil } \\
\text { NigOil - B }\end{array}$ & 96,5 & 91,53 \\
\hline $\begin{array}{l}\text { Olive oil Borgeos - } \\
\text { C }\end{array}$ & 83,6 & 78,58 \\
\hline $\begin{array}{l}\text { Olive oil Carapelli - } \\
\text { D }\end{array}$ & 64,6 & 61,89 \\
\hline
\end{tabular}

The antioxidant activity index is distributed in this method in the same correspondence: the best sample is $\mathrm{A}$, then the sample is $\mathrm{B}$, then the sample is $\mathrm{C}$, and the least antioxidant activity in olive oil of the sample is D. There is a correspondence between these two indicators, the higher the degree of radical seizure, the higher the degree of antioxidant activity. Olive oil samples also exhibited antioxidant 
properties when interacting with a stable free radical, but to a lesser extent than black cumin seed oil samples (Fig. 2), which is consistent with literature data (Makarova and Borodinova, 2011).

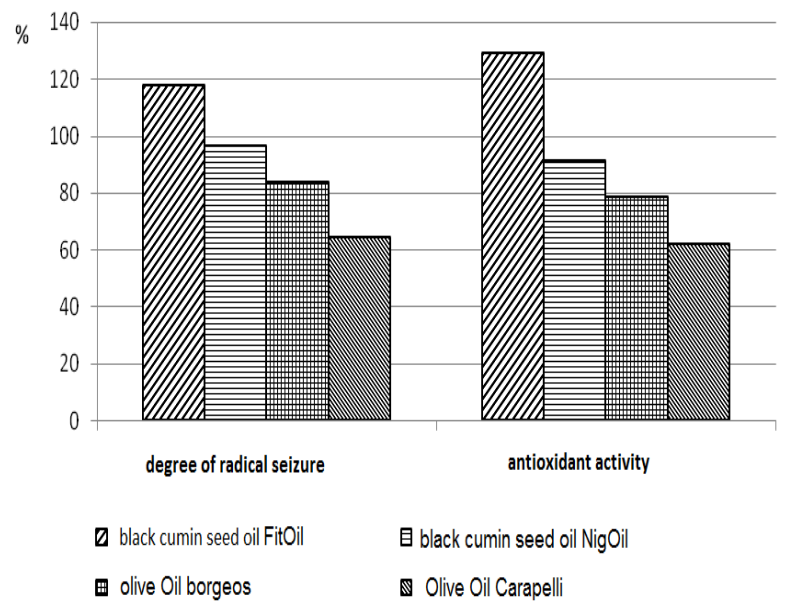

Figure 2. Comparative degree of antioxidant activity depending on the degree of radical seizure of various samples of olive oil and black cumin oil.

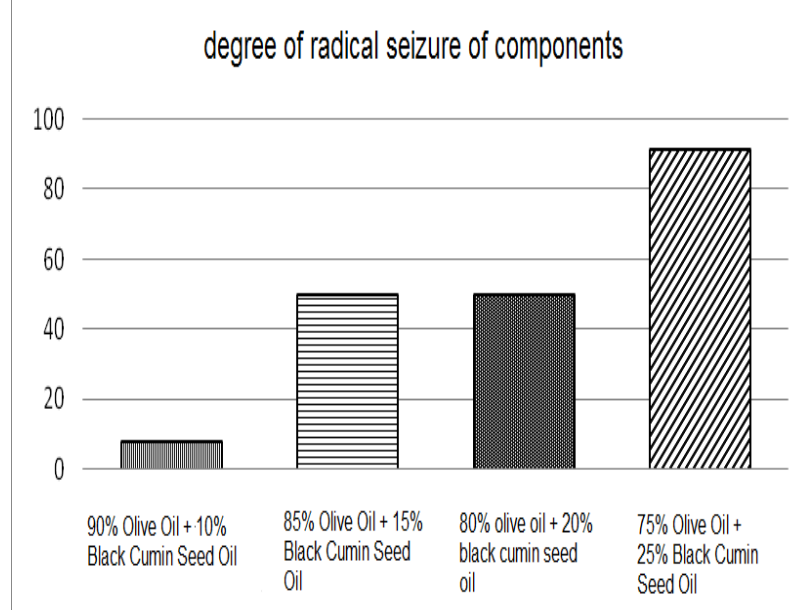

Figure 3. The change in the degree of radical seizure depending on the content of black cumin seed oil in olive oil

Black cumin seed oil was found to exhibit higher antioxidant activity than olive oil samples. Although samples of olive oil had a relatively high degree of radical seizure, i.e. antioxidant activity. Created compositions based on olive oil with the addition of black cumin seed oil in order to increase the degree of antioxidant activity of olive oils were investigated to change the antioxidant activity. Four different compositions of olive oil with the addition of black cumin seed oil: $\mathrm{E}$ - (A: $10 \%)$; - (A: 15\%); G - (A: 20\%); H - (A: $25 \%$ ) showed the following results of an increase in antioxidant activity (Fig. 3).

The presented results of changes in the degree of antioxidant activity of olive oil (AA) (radical free radical capture (DPPH) showed that the best results were achieved by adding $25 \%$ of black cumin seed oil to it, sample $\mathrm{H}$ (A: $25 \%$ ). When it is contained in olive oil $10 \%$ black cumin oil (sample E - (A: 10\%), olive oil practically does not change its antioxidant properties. Composition of olive oil $F$ (A: $15 \%$ ); and $\mathrm{G}$ with $20 \%$ black cumin oil (A: $20 \%$ ) have almost the same degree of antioxidant activity, and the ledge According to activity, only sample $H$ (A: $25 \%$ ) with a $25 \%$ black cumin oil content. It should be noted that the latter composition $\mathrm{H}$ (A: 25\%) was not inferior in terms of the degree of antioxidant activity to sample B of pure black cumin oil, however, it had less pronounced peculiar smell and taste of black cumin oil.As can be seen in the diagram (Fig. 3), the higher the content of black cumin oil in the mixture, the higher the antioxidant properties of the composition, however, the organoleptic characteristics of the compositions may vary depending on the original ingredients, which is a reason to consider options for improving the taste and antioxidant properties of this product. combination with the developed dish.The oxidizing ability of the components of olive oil, black cumin oil or their compositions was analyzed by cyclic voltammetry (CVA) in the anodic region of potentials from 0.5 to $2.0 \mathrm{~V}$. From literature sources (Sampiyev et al.,2014) it is known that in this range spatial-obstructed phenols (from 1.0 to $1.3 \mathrm{~V}$ ), which have a high antioxidant activity (Sampiyev et al., 2014). At higher potentials, five-membered O-, N-, Sheterocyclic compounds (from 1.5 to $2.0 \mathrm{~V}$ ) with high biological and physiological activity are oxidized. The CVA method, being a qualitative and quantitative analysis, which 
shows a linear dependence of the peak of the anodic current on the concentration of the active components of the studied oil samples (A - H), showed (Fig. 4) that with increasing concentration of the substance (black cumin oil in olive oil) in the electrochemical cell oxidation peaks grow according to current.

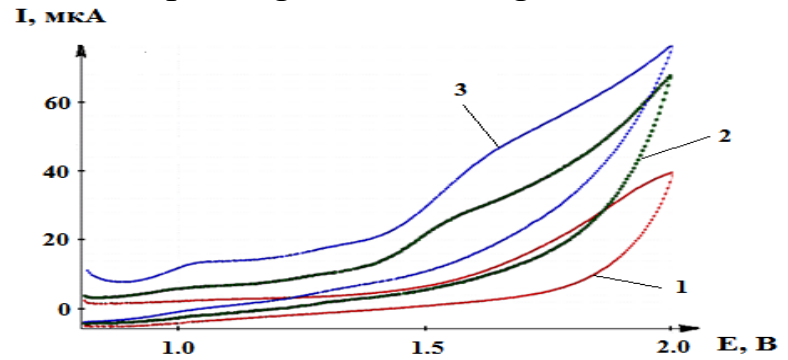

Figure 4. Cyclic voltammogram of oxidation: 1 - background electrolyte; 2 - components of black cumin oil (sample A) $(\mathrm{V}=100 \mu \mathrm{l}) ; 3$ components of black cumin oil (sample A) (V $=300 \mu \mathrm{l})(\mathrm{Pt}$-anode, $\mathrm{Ag} / \mathrm{AgCl}, \mathrm{CH} 2 \mathrm{Cl} 2,0.1$ $\mathrm{M}$ n-Bu4NClO4).

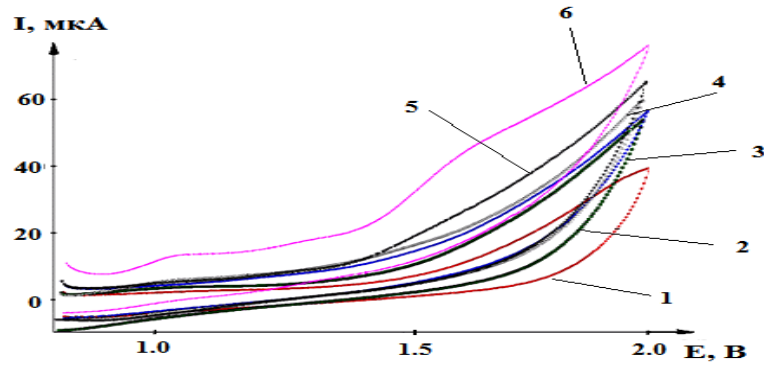

Figure 5. Cyclic voltammogram of oxidation $(\mathrm{V}=300 \mathrm{ml}): 1$ - background electrolyte; 2 - components of olive oil (sample C); 3 - components of a mixture of olive oil $(90 \%)$ and black cumin oil $(10 \%)$ (sample E A: $10 \%) ; 4$ - components of a mixture of olive oil $(80 \%)$ and black cumin oil (20\%) (sample G (A: $20 \%$ ); 5 - components of a mixture of olive oil (75\%) and black cumin oil (25\%) (sample $\mathrm{H}$ - A: 25\%); 6 - A components of the oil black cumin oil (Pt-anode, $\mathrm{Ag} / \mathrm{AgCl}, \mathrm{CH} 2 \mathrm{Cl} 2,0.1$ $\mathrm{M}$ n-Bu4NClO4).

Based on the analysis of cyclic voltammograms of oxidation of components contained in samples of black cumin oil (A, B), olive $(\mathrm{C}, \mathrm{D})$ and their compositions $(\mathrm{E}, \mathrm{F}, \mathrm{G}$, $\mathrm{H})$, it was found that in black cumin oil $(\mathrm{A}, \mathrm{B})$ there is the highest concentration of substances similar to spatially obstructed phenols (Fig.5).
Also in this sample A, the maximum content of heterocyclic oxygen -, nitrogen - or sulfurcontaining compounds is observed, and their concentration is 4-5 times higher than compounds of the class of phenols (Kouakou et al., 2018).

Accordingly, in the sample of olive oil C, the content of these valuable components is minimal.

The results of the study of the compositions of olive oil and black cumin oil in various percentages allow us to conclude that increasing the mass fraction of black cumin oil in olive oil of samples E, F, G, H from $10 \%$ to $25 \%$ increases the biological value and antioxidant activity of the mixture oils. This is due to the increase in the concentration of biologically active components and substances with antioxidant activity in it, as evidenced by the data of CVA method (Fig. 5).

According to the results of studies of literature data in the issues of improving consumer properties of the organoleptic characteristics and quality of vegetable oil, according to the specifics of the human body, methods of blending two or three different types of oil have been proposed (Sikoev, 2009).

\section{Conclusions}

On the basis of the obtained data, it is clear that the highest index of antioxidant activity was found in sample A and B of black cumin seed oil, which is consistent with the authors' opinion on the high nutritional, perfume and therapeutic activity of chernushka oils (black cumin - Nigella sativa). Samples of olive oil $(C, D)$ in this work had half the antioxidant activity (Muratova et al., 2016). It turned out that by adding black cumin seed oil to olive oil, it is possible to improve not only its organoleptic properties, but also antioxidant activity, which increases the possibility of creating new food products not only with improved taste data, but also with a targeted antioxidant effect (Makarova and Borodinova, 2011). The composition of olive oil with 15$20 \%$ content of black cumin seed oil (samples $\mathrm{F}, \mathrm{G}$ ) is optimal both for antioxidant activity 
and organoleptic properties. Therefore, this composition of oils can be recommended as a functional edible oil, which increases their consumer qualities (Mizhueva and Balashov, 2010). Earlier, an organoleptic analysis was performed, where the indicators taken into account included taste, aroma and appearance. As a result, according to the criterion for assessing the organoleptic characteristics of research objects expressed in points and their weight coefficients and based on the results of tasting, it was determined that the composition containing $80 \%$ olive oil and $20 \%$ black cumin oil had the best organoleptic characteristics (Shahin and Dolganova, 2014).

\section{References}

Bizer, M., Lund, H. (1988). Organic Electrochemistry: In two books, translated from English, Moscow, ed. Chemistry, (book.2), 1024.

Bordwell, F.J., Cheng Jin-Pei. (1989) Radicalcation acidities in solution and in gas phase. The Journal of the American Chemical Society, 111, (5), 1792 - 1795.

Elshafey, S.M.A., Abdelrakhman, A.A., Validov, Sh.Z., Bikmullin, A.G., Sanatova, E.R. Zalyalutdinova, L.M., Fattakhova, A.N., Alimov, F.K. (2014). The cytotoxic activity of vegetable oils of Nigella sativa, Salvia officinalis and peptide metabolites of Streptomyces mirabilis FK749 against cancer cell lines HeLa and MCF-7. Journal of Genes \& Cells, 9, (3), 295-302.

Fabris, S., Bertelle, M., Astafyeva, O., Gregoris, E., Zangrando, R., Gambaro, A., Lima, G.P.P., Stevanato R. (2013). Antioxidant properties and chemical composition of Europeans and Brazilians propolis. Pharmacology \& Pharmacy, 4, 64-51, DOI: 10.4236 / pp.2013.41006.

"GABRIS" food, black cumin oil. http://www.gabris.ru/gabris/health/tmin/oil/

Khasanov, V.V., Ryzhova, G.L., Maltseva, E.V. (2004). Methods for the study of antioxidants. Journal of Plant Chemistry, 3, 63-75.
Kouakou, S.L., Ouattara, M., Guessan, J.P. N., Coulibaly, S., Irié-N'Guessan, A.G., Kouakou-Siransy, G. (2018). Antioxidant and Cytotoxicity Potential of Six Synthesized Chalcones. Pharmacology \& Pharmacy, 9, 536-546, DOI: 10.4236 / pp.2018.912042.

Lemekhova, A.A., Nesterenko, E.A., Silantyev, L.A. (2011). Antioxidant properties of fermented milk product with sprouted barley grains. Scientific journal Processes and Apparatus for Food Production, 1, 154160.

Makarova, N.V., Borodinova, V.P. (2011). Creation of new foods with antioxidant action. Scientific and Production Journal Food Industry, 8, 16-17.

Mizhueva, S.A., Balashov, M.V. (2010). Analysis of the range and consumer preferences of vegetable oil sold in the market of Astrakhan. Materials of scientific and practical Internet conf. Astrakhan, www.konf.afurgi.ru.

Muratova, E.A. Daukaev, R.A. Afonkina, S.R. Mansurova, E.V. The problem of olive oil falsification and its detection methods (2016) Journal of Occupational Medicine and Human Ecology,1,62-66. https://cyberleninka.ru/article/n/problemafalsifikatsii-olivkovogo-masla-i-metody-eeobnaruzheniya

Olive oil tasting - Greek olivehttp://www.greekoliva.ru/content/22-oliveoil-degustation.

Sampiyev, A.M., Rud, N.K., Davitavyan, H.A. (2014). Phytochemical study of Chernushka sowing seeds. Scientific Journal of Basic Research, 5 (1), 114-117.

Shaheen,M., Dolganova, N.V. (2014)

Formulation of olive oil with enhanced functional and antioxidant properties. Scientific and practical journal "Technology and commodity research of innovative food products." - Oryol, GOU VPO "Oryol State Technical University", 3 (26), 56-63.

Shpigun, L.K., Zamyatina, N.N., Kamilova, P.M. (2010). Methods for quantifying the 
antioxidant activity of drugs based on free radical reactions. Collection of scientific conference - competition IONRAN, Moscow, 148-151.

Sikoev, Z.Kh. (2009). Improving the consumer properties of vegetable oil blending method. Proceedings of the Samara Scientific Center of the Russian Academy of Sciences, 11, 1 (5), 1094-1096.

\section{ACKNOWLEDGMENTS}

The work is supported by Ministry of High Education in Russia. All authors are thankful all staff in Astrakhan State Technical Univ., and thankful all staff in Astrakhan State Univ, Russia. 